\title{
Manfield and Sisson to Lead 2001 Meeting
}

APSA is pleased to announce the appointment of Edward D. Mansfield and Richard Sisson, both of Ohio State University, as Program Co-Chairs for the 2001 Annual Meeting. APSA will gather for its 97th Annual Meeting in San Francisco, California, August 30-September 2, 2001.

Edward Mansfield has research and teaching interests in international political economy and international security. His is the author of Power, Trade, and War (Princeton University Press, 1994) and recently coedited The Political Economy of Regionalism (Columbia University Press, 1997) and International Organization: A Reader (HarperCollins, 1994). He is currently coeditor of the series Michigan Studies on International Political Economy and serves on the editorial board of World Politics, the American Journal of Political Science, and Political Research Quarterly.

Richard Sisson is a scholar of comparative politics who focuses on legislatures, parties, electoral poli-

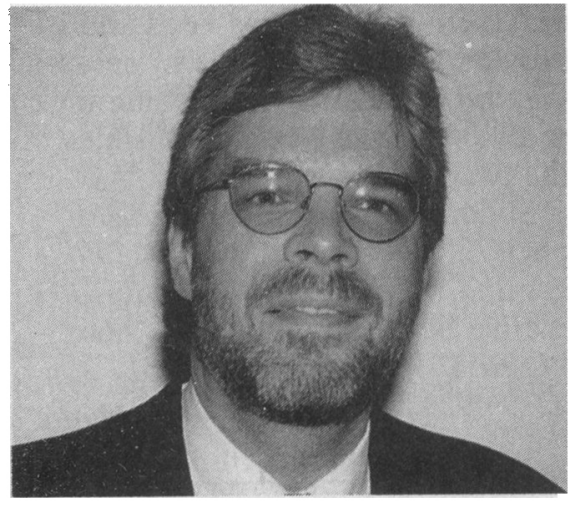

Edward Mansfield tics, and democratization in Asia, particularly in India. He is the author of War and Secession: Pakistan, India, and the Creation of Bangladesh (University of California Press, 1990); Congress and Indian Nationalism: The Pre-independence Phase (University of California Press, 1988); and The Congress Party in Rajasthan: Political Integration and Institution Building in an Indian State (University of California Press, 1971). He is currently senior advisor to the president of Ohio State and holds the Trustees Chair in Comparative Politics.

APSA will begin accepting proposals for the 2001 Annual Meeting in September 2000 for panels, papers, and posters related to the organizing theme as well as proposals addressing topics covering the 44 divisions, or subfields, of political science. Submission guidelines and instructions will be published in the September issue of PS, in the 2000 Annual Meeting Final Program, and on APSANet.

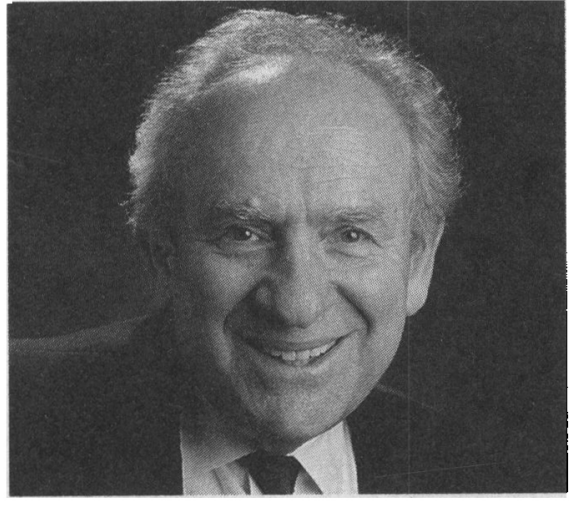

Richard Sisson

\section{APSA Produces Political Science Careers Video}

Working to provide departments with new resources for attracting students to the benefits of a political science major, APSA has teamed with Davis Gray, Inc. to produce Career Encounters: Political Science. The half-hour video features 10 people with meaningful and rewarding careers who studied political science in college. Their stories can carry the message about the value of undergraduate study in political science to students in colleges and universities and to high school students visiting campuses and classes.

It has been produced specifically as a resource for political science departments and faculty who face questions from students and their families about the skills and opportunities associated with the study of political science. It is accompanied by a guide for effectively integrating the video or segments from it in presentations. The video is designed to be shown in the classroom, at meetings for prospective majors, and at recruiting and career fairs.

The video was produced by APSA and sponsored by the Association's Departmental Services Program, with additional support from the Professional Opportunity Grant Fund allocated by the Committee on Education and Professional Development. The Career Encounters series is produced by Davis Gray, Inc.

\section{Listing of Doctoral Dissertations in Political Science Now Available Online}

The annual listing of dissertations completed in political science is now available as part of PSonline. Visit PSonline as part of the APSA web site at www. apsanet.org. Simply click on Dissertations and find the author, title, school or subject you seek. No more six-point type. No more failing to find the listings you seek due to fatigue, frustration, or faltering vision. Paper copies of the dissertation listing will be retained by APSA for archival purposes and will be sent to individuals with web access upon request from Editor, PS, American Political Science Association, 1527 New Hampshire Ave., NW, Washington, DC 20036-1206; (202) 483-2512. 